J. Pijar MIPA, Vol. V No.2, September : 49 - 52

ISSN 1907-1744

\title{
PENELITIAN TINDAKAN KELAS: ANTARA TEORI DAN PRAKTEK
}

\author{
A. Wahab Jufri \\ Program Studi Pendidikan Biologi PMIPA FKIP Universitas Mataram \\ Jl. Majapahit No. 62 Mataram 83125
}

\begin{abstract}
Abstrak : Penelitian tindakan kelas merupakan salah satu proses inkuiri yang penting untuk dilaksanakan oleh guru dalam rangka meningkatkan kualitas proses dan hasil belajar peserta didik. Ada tiga karakteristik PTK yang perlu dipahami yakni, 1) dilaku-kan atas dasar adanya masalah yang dipicu oleh kesadaran guru bahwa praktik pembelajaran yang dilakukannya di kelas memerlukan perbaikan, 2) merupakan suatu bentuk kegiatan inkuiri yang dilakukan melalui refleksi diri, dan 3) dilaksanakan di dalam kelas oleh guru secara terintegrasi dengan kegiatan pembelajaran dan dapat menjadi tindakan inovatif guru dalam proses pelaksanaan tugas profesinya. Dalam rangka mengembangkan semangat dan kemampuan guru untuk melaksanakan PTK maka guru perlu difasilitasi untuk berperan serta sebagai peneliti pendamping dosen, diciptakan peluang dan akses untuk mengikuti diseminasi tentang hasil penelitian dan teori-teori serta praktik PTK di sekolah.
\end{abstract}

Kata kunci : PTK, inkuiri, teori-praktik, peneliti pendamping

\section{CLASSROOM ACTION RESEARCH: THE GAP BETWEEN THEORY AND PRACTICES}

\begin{abstract}
Classroom action research is one form of teacher inquiry activities to improve the quality of teaching processes and student learning achievements. There are three important characteristics of classroom action research (CAR) that should be known by teacher. First, it is conducted by teacher based on their awareness in relation to his/her teaching process. Second, it is a teacher's inquiry activity which should be conducted through self reflection. Third, it is conducted by teacher as form of teaching innovation during his/her professional activities. In the efforts to develops teacher spirits and ability to proceeds classroom action research, therefore it is important to provide broad facility for teacher to be involved in lecturer's research activities as co-researcher and to joint dissemination of scientific articles about theories and practices of the lassroom action research.
\end{abstract}

Keywords : CAR, inquiry, theory-practices, co-researcher

\section{PENDAhUluan}

Penelitian tindakan kelas (classroom action research), pada umumnya diarti-kan sebagai suatu kegiatan inkuiri sistematis yang dilakukan oleh guru untuk meref-leksikan diri dalam upaya untuk meningkatkan kualitas proses dan hasil pembelajaran di kelas [1]. Dalam penelitian tindakan kelas (PTK), guru berperan sebagai peneliti di dalam kelas yang dikelolanya sendiri. Hal itulah yang membedakan PTK dengan penelitian-penelitian pendidikan lainnya yang lazimnya merupakan kegiatan peneliti dari luar dan memposisikan guru hanya sebagai pembantu pelaksana, atau sebagai subjek penelitian. Melalui refleksi diri dalam proses PTK, diharapkan guru dapat mengembangkan kemampuan-nya untuk mengidentifikasi masalah dari segi praktis baik secara kelembagaan maupun individual yang berkaitan dengan tugasnya. Guru juga diharapkan dapat meng-ambil tindakan untuk menyelesaikan masalah-masalah (to solve problems) pendidikan dan pembelajaran yang ditemukan dalam kelas yang diasuhnya.

Berkaitan dengan pengertian yang telah dikemukakan di atas, [7] menyatakan bahwa penelitian tindakan kelas memiliki karakteristik antara lain sebagai berikut:

1) PTK dilakukan atas dasar adanya masalah yang dipicu oleh kesadaran guru bahwa praktik pembelajaran yang dilakukannya di kelas memerlukan perbaikan. Dari karakteristik ini terlihat bahwa PTK berbeda dengan penelitian pendidikan jenis lain yang kebetulan dilaksanakan di kelas di mana adanya masalah ditengarai oleh peneliti yang berada di luar lingkungan kelas atau sekolah.
2) PTK merupakan suatu bentuk kegiatan inkuiri yang dilakukan melalui refleksi diri. Dalam hal ini guru sebagai peneliti dipersyaratkan untuk mengumpulkan data dari hasil praktiknya sendiri melalui proses refleksi diri.

3) PTK dilaksanakan di dalam kelas oleh guru sebagai peneliti utama, sehingga penelitian yang dilakukan terintegrasi dengan kegiatan pembelajaran dan dapat berupa perilaku atau tindakan inovatif guru dalam proses berinteraksi dengan siswa.

4) PTK bertujuan untuk memperbaiki kualitas pembelajaran. Dalam hal ini perbaikan dilakukan sendiri oleh guru secara bertahap dan berkesinambungan, selama proses pelaksanaan penelitian. Oleh karena itu, PTK dikenal juga sebagai penelitian bersiklus dengan tahapan yang meliputi perencanaan, pelaksanaan tindakan dan pengamatan (observasi), refleksi, dan penyusunan rencana perbaikan.

Kunci utama PTK yakni adanya tindakan pembelajaran yang dilakukan secara berulang (bersiklus) dalam rangka mencapai perbaikan yang diinginkan. Beberapa sasaran yang dapat ditempuh melalui PTK meliputi upaya-upaya perbaikan pola pemahaman siswa terhadap materi pelajaran, peningkatan kemam-puan guru dalam menerapkan strategi pembelajaran, pengembangan kompetensi guru dalam merancang atau menggunakan media tertentu, perubahan perilaku siswa menjadi lebih baik, dan pening-katan partisipasi siswa dalam proses belajar dan sebagainya. Satu hal yang perlu dipahami oleh pelaksana PTK adalah bahwa pola tindakan penyelesaian masalah yang dilakukan pada tiap-tiap siklus penelitian harus sama sedangkan materi pelajaran yang menjadi fokus pembahasan tidak harus sama. Dalam hal ini materi 
pelajaran terus berlanjut seiring dengan perencanaan kurikulum yang telah ditetapkan di sekolah. Hal menjadi penting untuk diperhatikan karena sementara ini masih banyak guru atau pendidik yang berpikiran bahwa suatu tindakan dala PTK dilaksanakan secara berulang dengan mengulang materi yang sama pada mata pelajaran tertentu.

\section{PEMBAHASAN \\ 2.1. Antara Teori dan Praktik Penelitian Tindakan Kelas}

Secara teoritis PTK memang seharusnya dapat dirasakan sebagai kebutuhan oleh para pendidik pada semua jenjang pendidikan. Akan tetapi dalam merancang dan melaksanakan PTK, masih cukup banyak pendidik yang merasa terbebani jika dituntut untuk melaksanakan PTK. Akibatnya, masih banyak guru yang tidak bahkan tidak mampu melaksanakan dan menulis hasil PTK.

Alasan-alasan yang menyebabkan kurang aktifnya guru melaksanakan kegiatan PTK antara lain ialah: Pertama, guru berpikir bahwa PTK adalah suatu proses dan produk dari kelompok di luar guru (outsider researcher). Peneliti yang berasal dari luar guru, merasa berperan sebagai ahli dalam menghasilkan teori dan juga cenderung mengasumsikan bahwa pengetahuan tentang pembelajaran harus dikeluar-kan berupa teori dari hasil pikiran peneliti. Oleh karena itu, peneliti selain guru sering-kali kurang memperhatikan guru pada saat mengembangkan suatu teori., Kedua, pandangan negatif terhadap teori PTK menjadi meningkat jika teori tersebut disampai-kan dalam bentuk generalisasi bagi praktik pembelajaran oleh guru secara keseluruhan. Semakin umum teori yang dikembangkan oleh peneliti, maka guru dan pihak sekolah akan semakin merasa terganggu sebab menurut pandangan guru, teori dapat berten-tangan dengan kenyataan yang terjadi atau dialami di sekolah. Ketiga, model yang dikembangkan oleh para ahli (peneliti luar) mungkin berasal dari kondisi masyarakat yang ideal. apabila guru menerapkannya di kelas dalam bentuk PTK, mungkin akan menimbulkan efek yang tidak diinginkan. Efek samping tersebut dapat: 1) meng-hasilkan ketidakseimbangan sosial dan ketidakadilan dalam masyarakat, 2) mening-katkan pola berpikir pasif dan menghambat berpikir kritis, 3) menggambarkan kedang-kalan dan keterbatasan konsepsi mengenai potensi kemampuan manusia sehingga mengurangi rasa percaya diri dan menghambat perkembangan individual, 4) memu-tus-kan perolehan pengetahuan dari pengembangan kapasitas untuk menilai dan diskri-minasi dalam kompleksitas kehidupan sehari-hari.

Generalisasi sebenarnya tidak secara langsung membebani atau mengancam posisi guru sebab generalisasi menunjukkan keteraturan di mana guru secara individual tidak mampu mengontrolnya. Hal lain yang membebani guru adalah bahwa generalisasi mengimplikasikan evaluasi negatif guru seperti kegagalan untuk melaksanakan model ideal pembelajaran. Secara teoritis, generalisasi memposisikan guru pada apa yang disebut oleh Ronald Lang [6] sebagai situasi ikatan ganda (double band) di mana guru dianggap bersalah meskipun sebenarnya guru telah melaksanakan tugasnya dalam keadaan menghindari kesalahan.
Singkatnya dalam upaya melakukan perubahan melalui pelaksanaan PTK guru berhadapan dengan berbagai masalah baik yang bersifat eksternal maupun internal. Masalah-masalah eksternal dapat berupa: 1) kurang jelasnya hubungan antara model pembelajaran teoritis dan penerapannya di kelas, 2) padatnya kurikulum dan silabus yang harus dilakukan guru dalam menjalankan tugas kesehariannya, 3) adanya tuntutan terhadap guru untuk mengejar target silabus dan mempersiapkan siswa agar berhasil melewati ujian yang umumnya berbasis kognitif [7]. Sedangkan masalah yang bersifat internal dapat berupa keengganan guru untuk melakukan perubahan karena kurangnya motivasi guru dan kurangnya akses guru terhadap sumber-sumber informasi berupa perpustakaan yang menyediakan literatur seperti jurnal, buku, majalah dan internet.

Dalam uraian di atas terlihat adanya kesenjangan antara teori dan praktik penelitian tindakan kelas bagi guru. Di satu sisi guru dituntut untuk mengadakan perubahan melalui kemampuan merancang dan melaksanakan penelitian tindakan kelas, sementara di sisi lain guru menghadapi tuntutan birokrasi dan praktik politis misalnya pencapaian target kurikulum dan target kelulusan. Kedua hal itu, menempatkan guru pada posisi yang dilematis. Kondisi seperti inilah yang menyebab-kan guru merasa terbebani oleh adanya teori yang merekomendasikan guru untuk melakukan penelitian tindakan kelas.

\subsection{Meretas Kesenjangan Antara Teori dan Praktik}

Adanya kesenjangan antara teori dan praktik dalam hal penelitian tindakan kelas ini, perlu diatasi secara berasama-sama oleh peneliti, pendidik dan ahli pendidikan, pengembang kurikulum, serta pemerhati pendidikan. [7] mengusulkan empat hal yang perlu untuk mendu-kung perkembangan profesional guru melalui penelitian tindakan kelas yaitu: 1) memotivasi guru untuk melakukan penelitian sendiri, 2) melibatkan guru sebagai peneliti pendamping (co-researcher) dalam mengembangkan teori baru, 3) menye-dia-kan akses untuk diseminasi literatur terkait penelitian, dan 4) menyediakan dukungan sesuai dengan kebutuhan guru.

Persyaratan esensial bagi guru untuk dapat menerima dan bersedia melakukan perubahan adalah motivasi untuk mengetahui tentang perubahan dan mempelajari bagaimana suatu teori tentang perubahan itu dapat mempengaruhi kemampuan guru dan pendidik pada umumnya. Memang tidak mudah bagi guru untuk menerima dan menerapkan suatu teori yang dipandang mungkin akan semakin membebani profesinya. Di samping itu, memang beban tugas guru khususnya di Indonesia, sudah terlalu banyak. Misalnya adanya tuntutan agar siswa mendapatkan nilai ujian nasional atau nilai ujian akhir sejenis yang tinggi sehingga nama sekolah tempat guru bertugas akan turut terangkat. Selain itu, guru mungkin merasa sulit untuk melakukan penelitian karena memang tidak memiliki kemampuan tentang prosedur penelitian dan juga kurang memahami manfaat dari penelitian. Oleh karena itu adalah sangat wajar jika pemangku kepentingan (stakeholder) pendidikan dapat memberikan dukungan dan pengharagaan kepada guru untuk melakukan penelitian tindakan kelas dalam bidangnya sesuai dengan kebutuhan 
siswa, kebutuhan sekolah, dan kebutuhan profesi guru sendiri. Dukungan dan penghargaan dapat berupa penawaran kesempatan untuk studi lanjut ke jenjang yang lebih tinggi (minimal jenjang S2).

Faktor lain yang perlu dilakukan untuk membantu guru mengembangkan profe-sio-nalismenya adalah menyediakan kemudahan akses ke dalam diseminasi literatur terkait penelitian tindakan kelas. Sehubungan dengan kesibukan guru dalam menjalan-kan tugasnya, maka kesempatan untuk mencari bahan bacaan yang terkait PTK mungkin akan sangat terbatas. Hal ini bisa menjadi salah satu penyebab guru tidak mampu merancang dan mengimplemen-tasikan PTK. Oleh karena itu, dalam rangka membantu guru, maka sekolah dan instansi terkait perlu menyediakan sumber-sumber informasi yang akurat, relevan dan mudah diakses. Ketersediaan internet dan literatur-litertur dalam bentuk jurnal hasil PTK dan bukubuku yang mudah diakses oleh guru akan menjadi bagian dari faktor pendukung yang penting untuk menumbuhkan motivasi guru untuk melaksanakan PTK.

Akses untuk diseminasi hasil penelitian tindakan kelas, juga merupakan hal yang perlu diperhatikan [1]. Workshop dan seminar perencanaan dan evaluasi hasil PTK perlu menjadi program prioritas bagi LPTK. Demikian juga halnya dengan sekolah dan pemerintah, harus memfasilitasi guru untuk berperan aktif dalam kegiatan ilmiah terkait PTK ini. Dengan adanya kesempatan untuk mem-presentasikan dan mendiskusikan perencanaan maupun hasil penelitiannya, guru akan menjadi lebih percaya diri dan dapat berperan lebih aktif dalam melaksanakan penelitian untuk menunjang kemajuan pendidikan dan mendukung proses perkembangan profe-sionalismenya.

Program melibatkan guru dalam proses penelitian tindakan kelas adalah aspek lain yang dapat mempengaruhi motivasi guru. Seperti telah disebutkan di atas, keengganan guru untuk menerima dan mengimplementasikan teori mengenai PTK dipengaruhi oleh kurangnya pengalaman guru dan minimnya kesempatan bagi guru untuk menjadi guru-peneliti (teacher-researcher). Jika selama ini guru tidak banyak dilibatkan dalam proses pengembangan teori baru, maka sekarang harus dipikirkan cara untuk melibatkan guru secara aktif dalam proses PTK. Oleh karena itu, bagi peneliti luar (outsider) yang ingin melaksanakan penelitian tindakan kelas hendaknya dapat melibatkan guru secara langsung sebagai peneliti pendamping. Dengan demikian, guru akan merasa memiliki rasa turut bertang-gungjawab terhadap teori yang dikem-bangkan dan akan berusaha memberikan kontribusi pada proses keberlangsungan penerapan teori tersebut.

Dalam rangka mengembangakan motivasi guru dalam penerapan PTK perlu juga dipikirkan penghargaan atau insentif yang didapatkan oleh guru. Pemerintah Daerah c.q Dinas Pendidikan perlu sekali memprogramkan kegiatan PTK bagi guru dengan dana yang dialokasikan secara berkesinambungan dalam anggaran pembangunana daerah. [6] menyatakan bahwa untuk melakukan sesuatu hal yang baru, sebagai manusia guru membutuhkan adanya insentif yang memadai. Guru tentu akan merasa terbebani dan tidak ingin terlibat dalam sesuatu yang bersifat ekstra tetapi tidak memberikan manfaat langsung seperti adanya penghasilan tambahan atau promosi jabatan. Selain insentif langsung, guru juga harus diberikan kemudahan untuk mendapat dukungan dari ahli atau peneliti luar (outsider) dalam bentuk bimbingan sehingga guru dapat berpikir, mengevaluasi, dan menemukan cara terbaik dalam merencanakan dan mengimplemen-tasikan PTK sebagai bagian dari sarana untuk berubah dan berkembang sesuai dengan tuntutan profesionalisme guru.

\subsection{Tujuan dan Manfaat PTK Bagi Guru}

PTK umumnya diarahkan untuk mencapai sasaransasaran tertentu seperti: 1) memperbaiki dan meningkatkan kualitas isi, proses dan hasil pembelajaran, 2) menumbuhkembangkan kebiasaan meneliti para guru agar lebih proaktif mencari solusi masalah pembelajaran, 3) mengembangkan produktivitas meneliti, dan 4) mengem-bangkan kolaborasi antara dosen LPTK dengan guru di sekolah [5].

Terkait dengan tujuan-tujuan tersebut maka muncul pertanyaan "mengapa guru harus mau dan mampu mengimplentasikan teori penelitian tindakan kelas sebagai suatu kebutuhan dan tantangan bagi pengembangan profesionalismenya? Sebagai jawaban atas pertanyaan tersebut, maka berikut ini disajikan beberapa manfaat PTK yang harus disadari dan diketahui oleh guru agar tidak merasa terbebani oleh beragam teori dan informasi tentang praktik PTK.

Pertama, penelitian tindakan adalah salah satu cara bagi guru untuk melibatkan diri secara langsung dalam proses pengembangan pem-belajaran di kelas dan mengeks-plorasi isu-isu yang dihadapinya dalam upaya mere-formasi kurikulum. Dengan dikem-bangkannya kurikulum berbasis sekolah atau kurikulum tingkat satuan pendidikan, maka melalui PTK guru harus mulai berani mencoba mengemukakan gagasan-gagasan baru yang didapatkannya dari proses refleksi diri sehingga akan dapat memberikan kontri-busi bagi pengembangan teori baru dalam bidang pembelajaran. Kegiatan penelitian tindakan kelas telah banyak dilakukan di banyak negara. Guru-guru pada semua jenjang pendidikan di Amerika Serikat, Canada, dan beberapa Negara maju lainnya telah mampu berbicara banyak dan memberikan kontribusi dalam proses reformasi kuri-kulum sekolah khususnya dalam bidang sains [2], [3], [4].

Kedua, melalui penelitian tindakan kelas, guru secara personal maupun profesional akan mendapatkan ganjaran. Secara personal guru akan mendapatkan insentif langsung jika berhasil memenangkan kompetisi untuk mendapatkan dana sebagai guru peneliti (teacherresearcher), atau jika terlibat sebagai pembantu peneliti (co-researcher) dalam proyek-proyek peneliti luar misalnya dosen. Sedangkan secara profesional guru akan mendapat ganjaran berupa kesempatan berinteraksi dengan guru-guru lain yang memiliki motivasi sama, serta dengan para ahli melalui diseminasi hasil penelitian serta ganjaran berupa promosi pangkat dan jabatan.

Ketiga, penelitian tindakan kelas akan menyediakan bukti mendasar bagi peningkatan praktik pembelajaran oleh guru dan dapat meningkatkan perolehan hasil belajar dan keterampilan berpikir, sikap dan kerjasama siswa. Hal ini tentu akan mendukung proses reformasi pendidikan 
yang bertujuan untuk mengem-bangkan kompetensi dasar siswa.

\section{KESIMPULAN}

Secara umum memang ada kesenjangan antara teori dan praktik mengenai penelitian tindakan kelas. Tidak sedikit jumlah guru pada jenjang pendidikan dan menengah bahkan dosen yang merasa terbebani dengan adanya tuntutan agar mau dan mampu melaksanakan penelitian tindakan kelas. Di sisi lain, guru harus memikul beban tugas dan tanggung jawab administratif yang beragam. Akibatnya guru semakin merasa tidak memiliki kemampuan dan kesempatan yang memadai untuk melakukan PTK. Oleh karena itu, diperlukan upaya untuk memotivasi guru agar tertarik untuk melakukan penelitian atas inisiatif sendiri. Pelibatan guru sebagai peneliti pendamping (co-researcher) bagi dosen dalam pelaksanaan PTK tentu akan sangat membantu guru. Selain itu perlu diciptakan peluang dan akses bagi guru untuk mengikuti diseminasi literatur terkait penelitian, serta pemberian dukungan bagi guru terutama pada fase-fase kritis yang dihadapinya berkaitan dengan penelitian tindakan kelas.

\section{DAFTAR PUSTAKA}

[1] Capobianco,B., R. Horowitz., D.C. Browne., R. Trimarchi. 2008. Action Research For Teacher, The Science Teacher, Vol. 71 No. 3 p: 48-53.

[2] Galus Pamela, J., 2002. Clasroom Composting, Creating Compost Using an Inquiry Based Design. The Science Teacher, vol. 69, No.9p:26-30.

[3] Hayes, C. 2004. Praise Acres Project An Idea From a Local Resident Turns Into a Project That Enhances High School Curriculum. The Science Teacher, vol. 71 No. 5.

[4] Harland, K. 2003. The Real Fish Story, Students Raise Salmon and Ecological Awarenes. The Science Teacher, vol 70. No. 5 p: $24-27$.

[5] Tantra, D.K. 2005. Konsep Dasar dan Karakteristik ;Penelitian Tindakan Kelas. Materi Pelatihan Metodologi Penelitian Tindakan Kelas, di Batam, diselenggarakan oleh Dit PPTK dan KPT, Dirjen Dikti Depdiknas.

[6] Taplin, M. 2004. A Framework to Facilitate Profesional Growth in Matehmatics Teaching Through Action Research. Paper in Subject Teaching and Teacher Education in the New Century, Research and Innovation, ed. Cheng, Y.C., K.T.Tsui., K.W. Chow., M. M.C. Mok. The Hongkong Institute of Education, Hongkong.

[7] Wardani, I.G.K., K. Wihardita., N. Nasoetion., 2004. Penelitian Tindakan Kelas. Pusat Penerbitan Universitas Terbuka. Jakarta. 